\title{
EFFECTIVENESS OF AGRICULTURAL EXTENSION IN THE AREA OF TOMATOES CROP PRODUCTION IN FAYOUM AND QALIUBIA GOVERNORATES
}

\author{
(Received: 6.6.2011)
}

\author{
By \\ A. A. Azam and A. H. Zyada* \\ Agricultural Extension \& Rural Sociology Department, Faculty of Agriculture, Cairo University \\ *Agricultural Extension \& Rural Development Research Institute, Agricultural Research Center, Giza, Egypt
}

\begin{abstract}
This study aimed to investigate the effectiveness of agricultural extension in the area of tomatoes production (EAEATCP), to determine the relationship between the degree of (EAEATCP) as a dependent variable and some independent variables, to detect the differences between the degrees of (EAEATCP) in each of the studied provinces, for identifying the problems facing tomato growers in the area of production, as well as to identify their suggestions to overcome these problems.

The present study was conducted in Fayoum and Qaliubia Governorates as the largest governorates of the area cultivated with tomato. Three districts were selected from each governorate: Qalyoub, Khanka, and Tukh of Qaliubia Governorate. Tamiya, Etsa, and Abshwai of Fayoum Governorate, the largest village of each district was selected according to the same criteria, these villages were: Qalyoub, Sariaqos and Qaha from Qaliubia Governorate, and Mataty, El- Gharaq El-Bahary, and Abu Denqash from Fayoum Governorate.

Data were collected through personal interview using a questionnaire from 358 respondents in the studied villages.

Frequencies, percentages, means, standard deviation, Pearson simple correlation coefficient, $\mathrm{t}$ test, were used in the presentation and data analysis.

The most important findings could be summarized as follows

-Obtained results showed that $8.4 \%$ of the respondents had a low level of knowledge of the studied recommendations, $65.5 \%$ were medium, while $26.1 \%$ were high.

-The results revealed that $82.7 \%$ of the respondents had low sources of knowledge of the studied recommendations, $4.2 \%$ were medium, while $13.1 \%$ had good sources of knowledge.

-The results showed that $8.4 \%$ of the respondents had a low level of implementation of the studied recommendations, $76.3 \%$ were medium, while $15.3 \%$ were high.

Obtained results showed that $44.7 \%$ of the respondents had a low level of benefit from studied recommendations, $51.1 \%$ were medium, while $4.3 \%$ had high benefit from implementation of the studied recommendations.

-The results revealed that $13.7 \%$ of respondents believed that the extension has low effectiveness in the production of tomato crop, $72.4 \%$ medium, while $13.9 \%$ high effectiveness.

-There was significant relationship at the level 0.01 between the degree of (EAEATCP) and each of the following: degree education, average tomatoe productivity, degree of communication with the change agents, degree of leadership, and degree of the attitude towards extension activities, and the relationship was significant at the level 0.05 with the area of agricultural holdings.

-There was significant difference between the degrees of (EAEATCP) in both of Fayoum and Qaliubia Governorates. The calculated $t$ value was 3.072 which is more than tabular $t$ value at the level 0.01 .

-The results showed that the most important problems facing tomatoe farmer were: low productivity per feddan, spread of diseases and insects, high prices of seedlings, the difficulty to serve good seedlings, not to follow the agricultural cycle.

-The main suggestions of the respondents to overcome these problems are: to provide the elements of agricultural production at inexpensive prices, follow the agricultural cycle, good service of the crop, spraying sulfur to reduce pesticide use, and limiting the use of fertilizers and pesticides.
\end{abstract}


Key words: agricultural extension effectiveness, tomatoes production.

فعالية الإرشاد الزراعي في مجال إنتاج محصول الطماطم بمحافظتي القليوبية والفيوم

عبد الثافي أحمد عزام -عبد الكريم حامد زيادةة

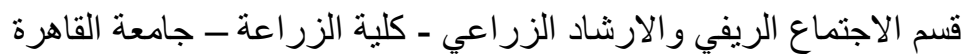

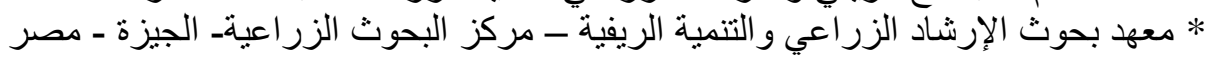

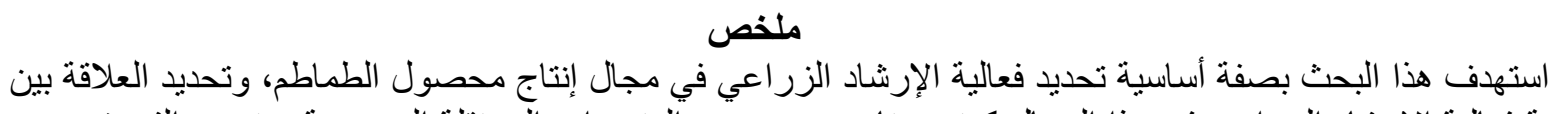

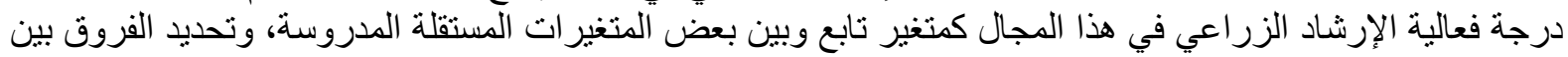

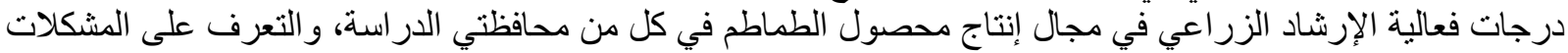

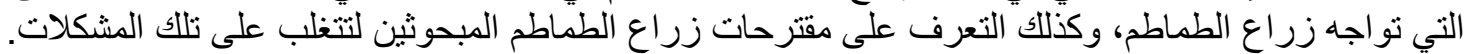

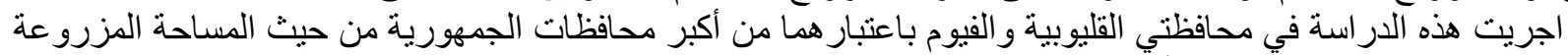

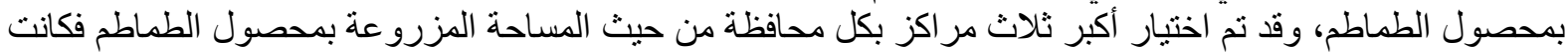

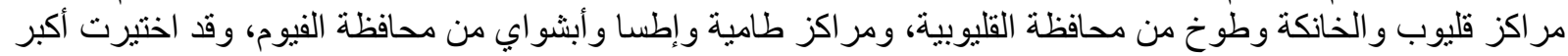

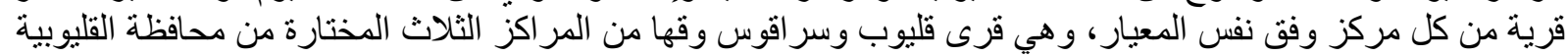

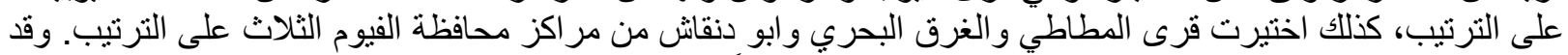

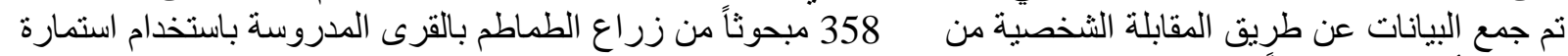

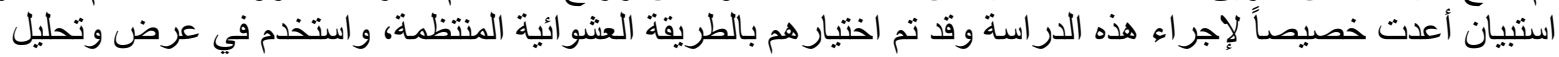

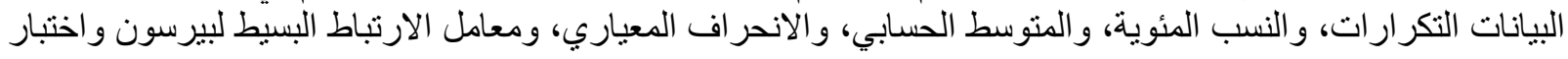

ويمكن تلخيص أهم نتائج الدراسة فيما يلي:

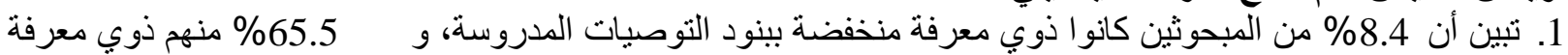

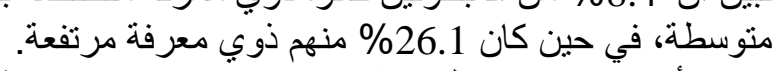

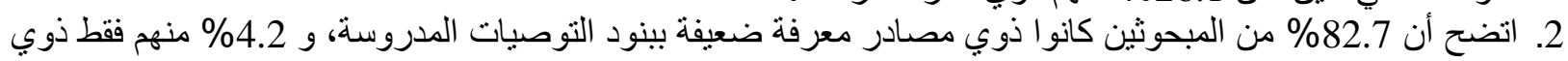

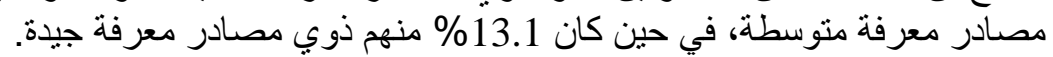

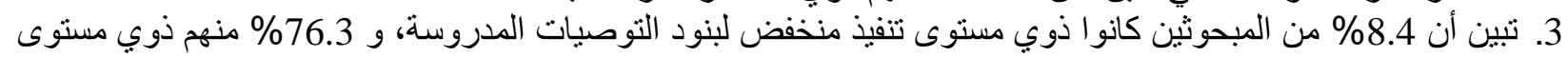

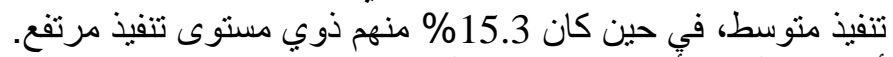

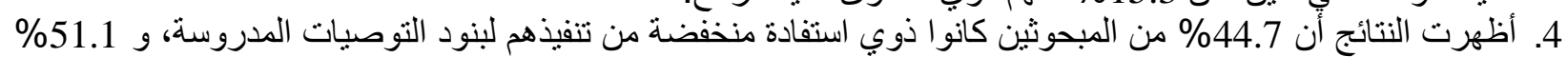

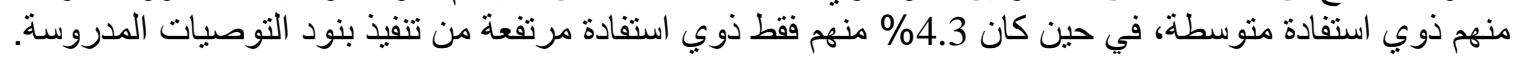

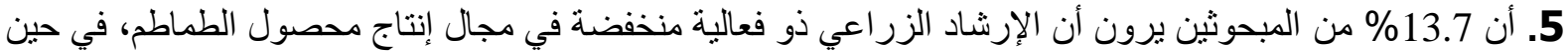

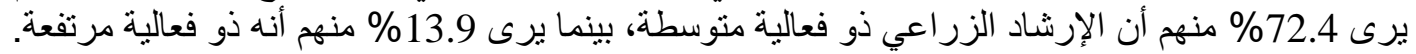

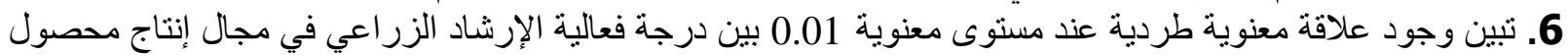

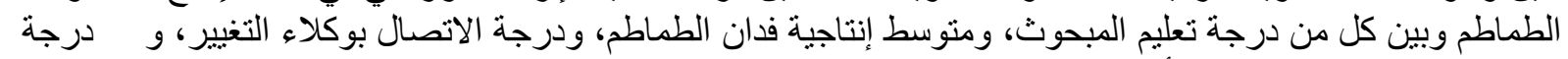

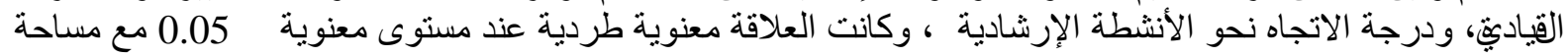

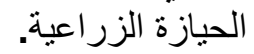

7. تبين وجود فرقاً معنوياً بين درجات فعالية الإرشاد الزر اعي في مجال إنتاج محصول الطماطم في كل من محافظتي الفيوم

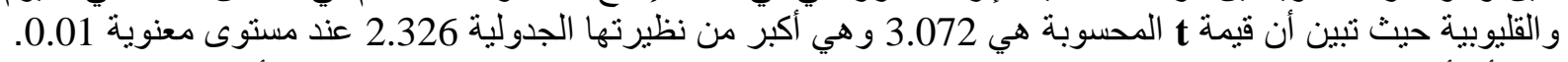

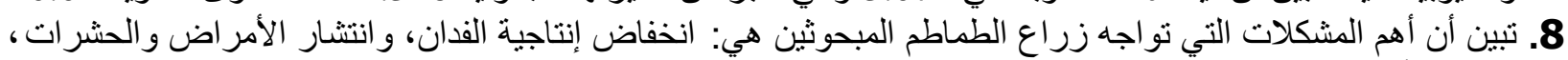

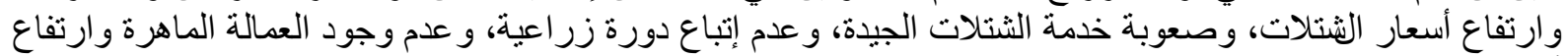
أجور ها. 


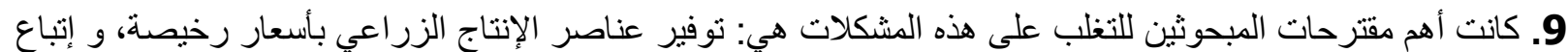
الدورة الزراعية، و الخدمة الجيدة للمحصول، والرش بالفين بالكبريت لتقليل استخدام المبيد، و عدم الإسر الف في استخدام الأسمدة

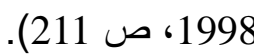

ويقوم جهاز الإرشاد الزراعي عن طرئ طريق الإدارة

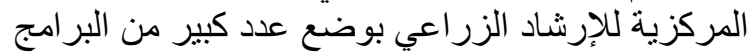

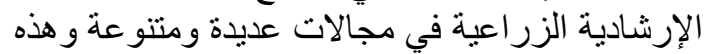

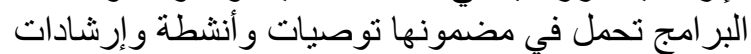

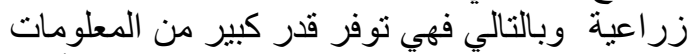

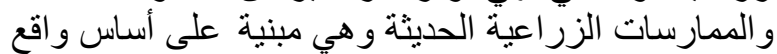

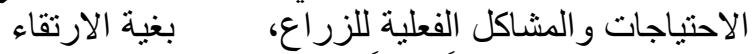

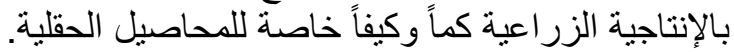
يمثل إنتاج الخضر في مصر جاعنب أساسي من الزئي الإنتاج

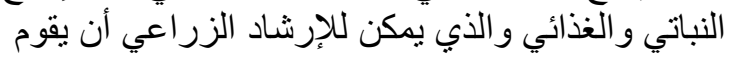

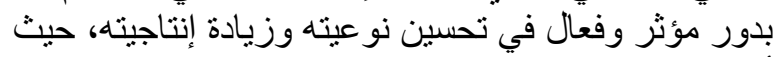

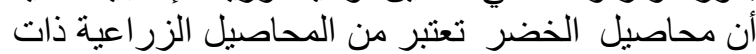

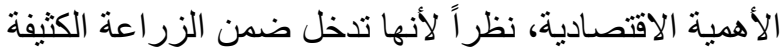

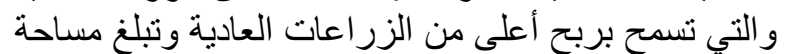
الخضر في مصر في الوقت الحاضر حوالئ الزئ 1.5 مليون 1.5

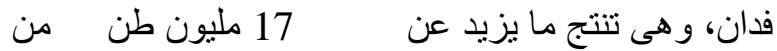

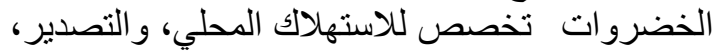

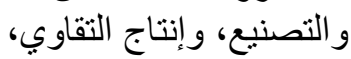

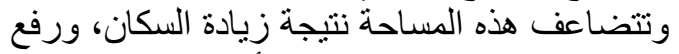

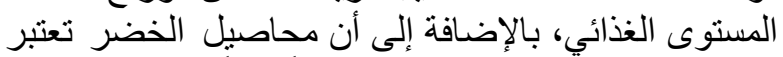

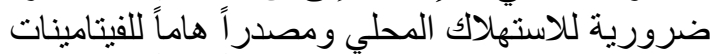

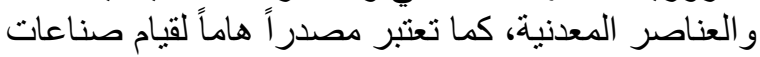

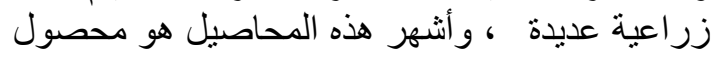

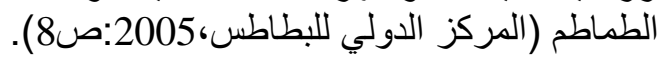

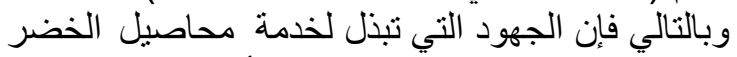

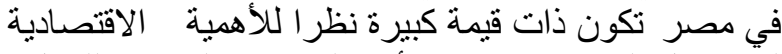

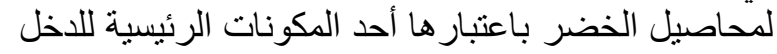

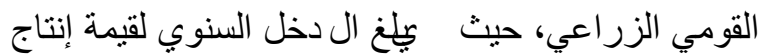

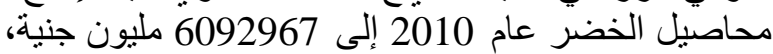

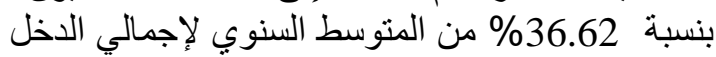
الزر اعي و البالغ 21934681 مليون جنية في الإلعام ( الإدارة

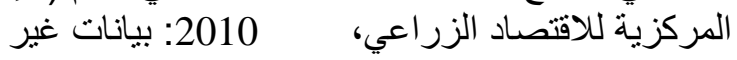

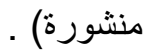

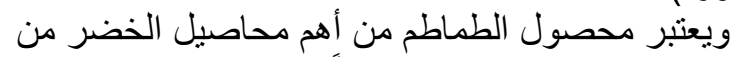

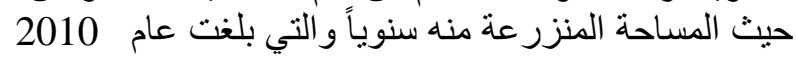
حو الي 344562 فدان وبلغ الإنتاج الكلي منها

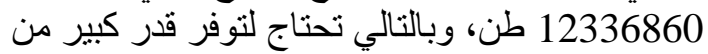

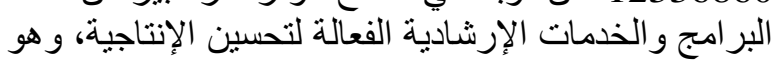
ما يتطلب بالضرورة العمل على التقييم المستمر لهذه الإنها

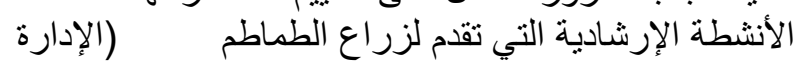

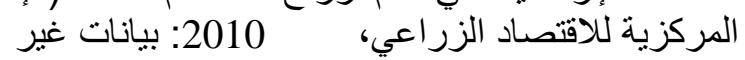
منشورة). من هنا يجب أن تكون الفعالية هي المنطلق الأساسي

\section{1. المقدمة والمشكلة البحثية}

يعتبر الدور الأساسي والجوهة والمري للإرشاد الزئة الزراعي

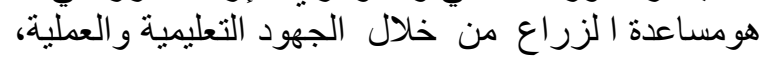

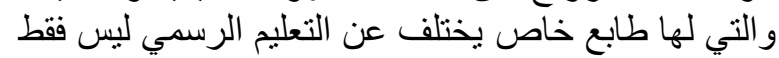

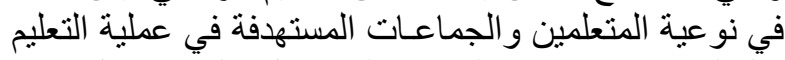

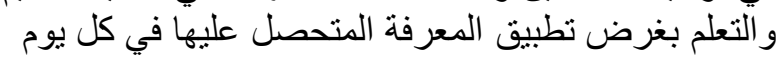

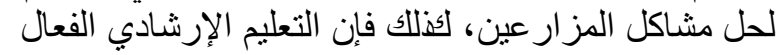

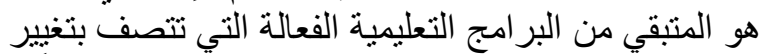

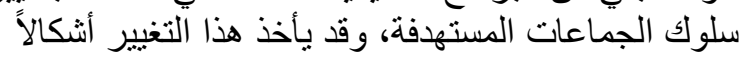

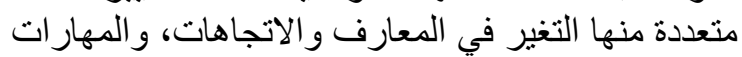

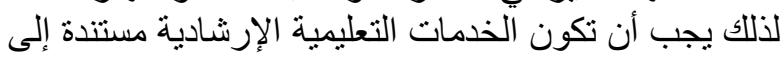

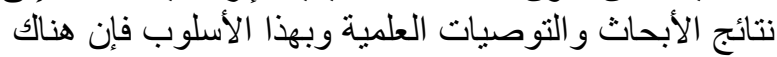

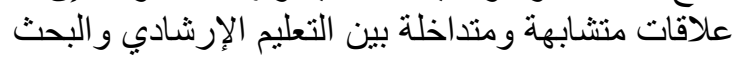

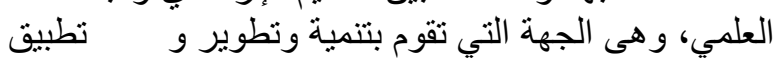

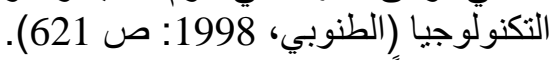

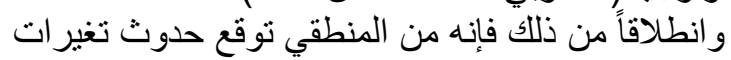

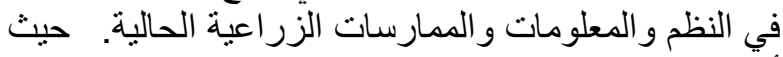

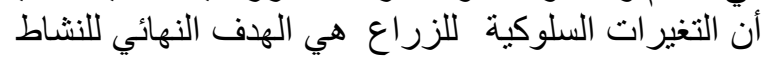

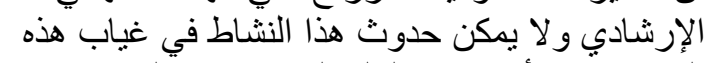

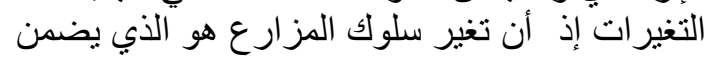

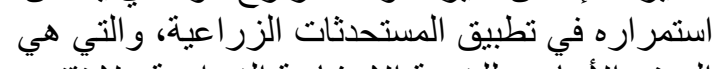

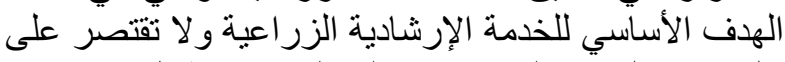

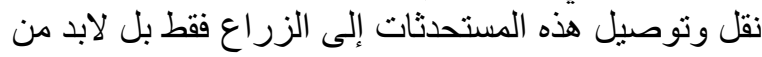

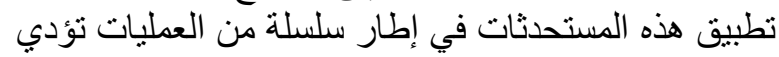

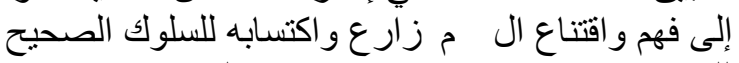

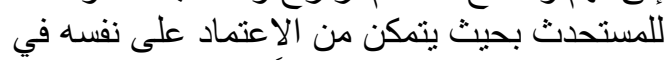

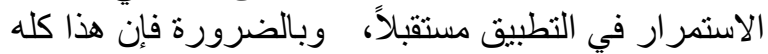

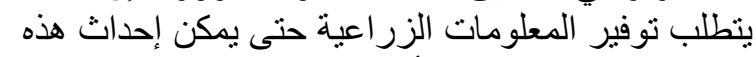

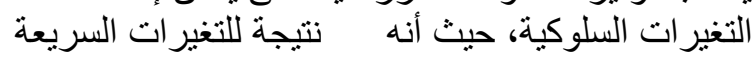

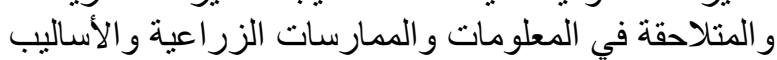

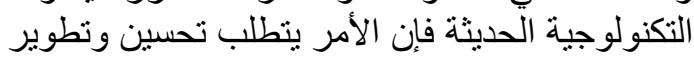

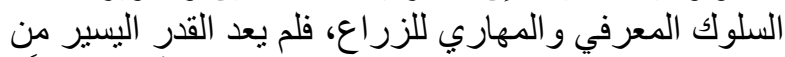

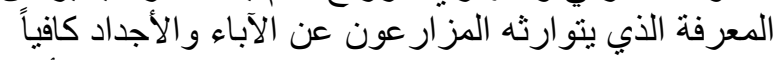

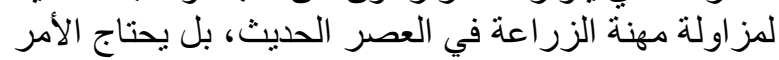

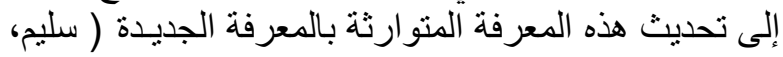

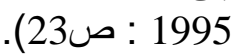

ومن هنا يتضح أهمية الإرشاد الزراعي في تتمية

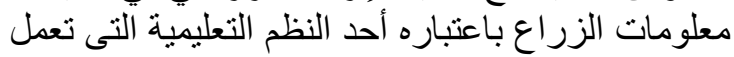

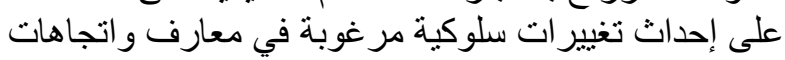

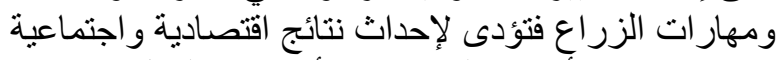

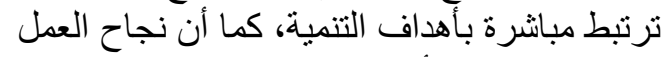

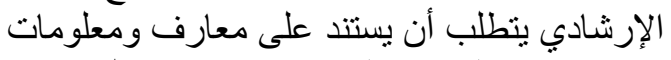

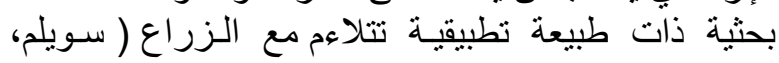




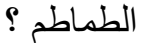

2- ما هي درجة استفادة زراع محصول الطماطم من جهود و أنشطة الإرشاد الزر اعي ؟

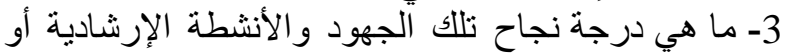

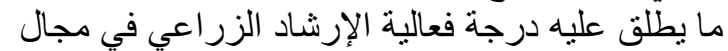

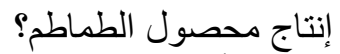
4- ما هي أهم المشكلات التي تولاجهاه زراع الطماطم في

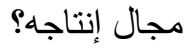

5- ما هي أهم مقترحاتهم للتغلب على هذه المشك إنكلات؟

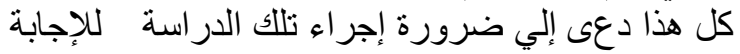

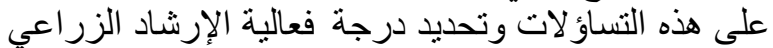

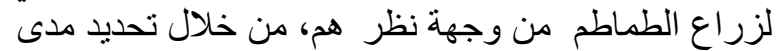

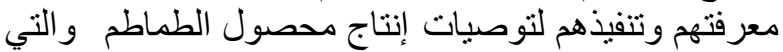

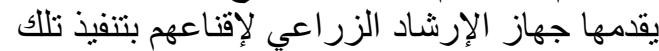

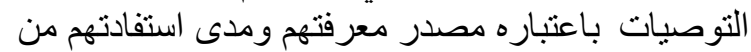

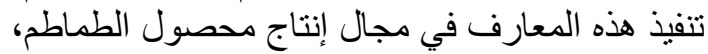

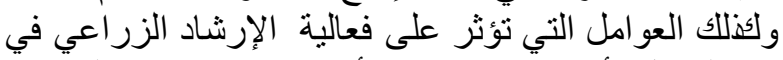

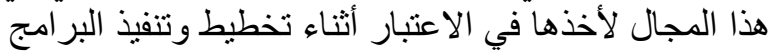
الإرشادية.

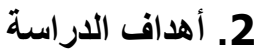
للإجابة على تساؤلات المشكلة البحثية فقد تحددت أهداف

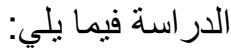
1. تحديد مسنوى فعالية الإرشاد الزر اعي في مجال إنتاج محصول الطماطم.

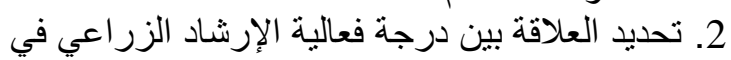

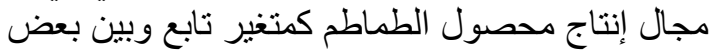

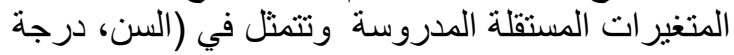

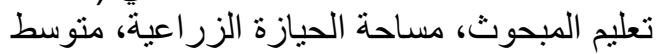

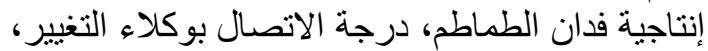

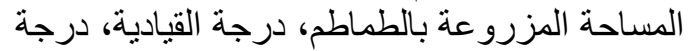
الاتجاه نحو الأنشطة الإرشادية).

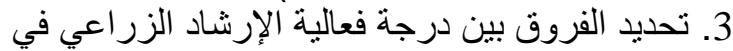

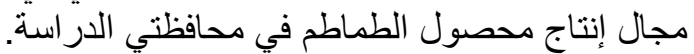

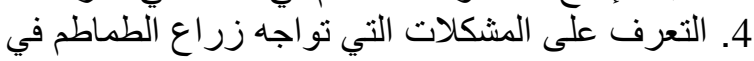
مجال إنتاجها. 5. التعرف على مقترحات زراع البتاع الطماطم المبحوثين للتغلب على المشكلات التي تو اجهُه.

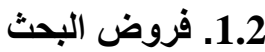
توجد علاقة معنوية بين درجة فعالية الإرشاد الزر اعي باعي

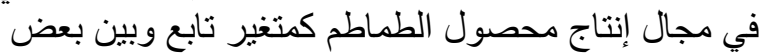

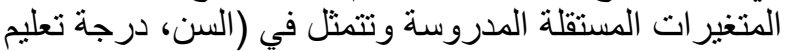

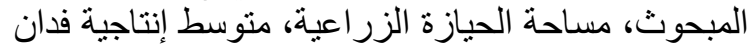

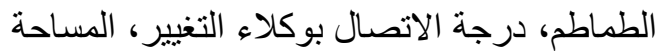

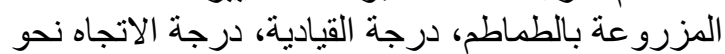
الأنشطة الإرشادية).

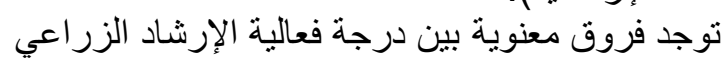
في مجال إنتاج محصول الطماطم في محافظتي الدراسة.
لمنظمة الإرشاد الزر اعي لتحسين أداء خدماتها للريفيين

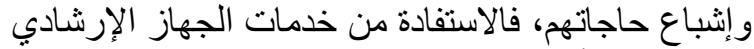

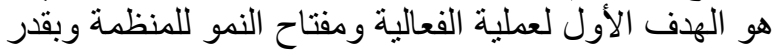

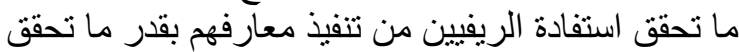

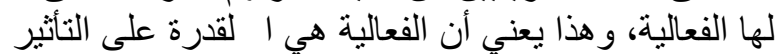

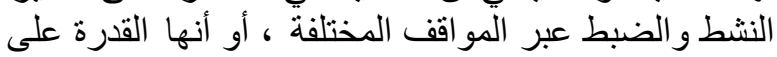

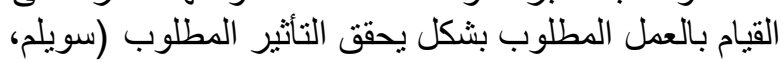

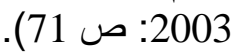

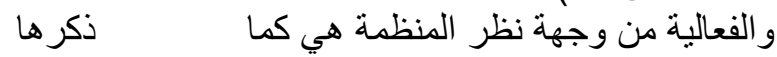

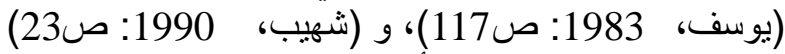
تعني مدى تحقيق المنظمة لأهدافها من خلال مو ارد محددة.

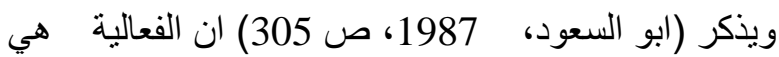

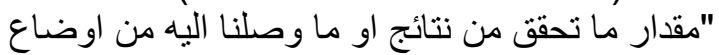

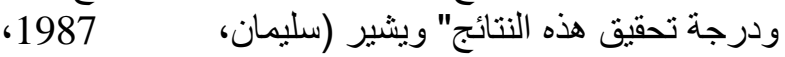

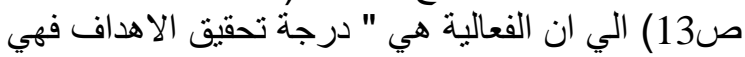
تعبر عن درجة تطابق مو أصفات المنتج النهائي علي الأي

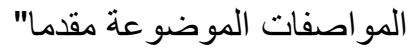

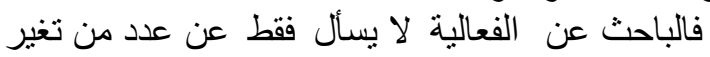

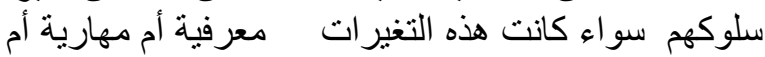

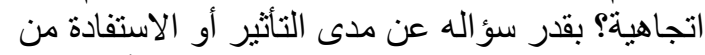

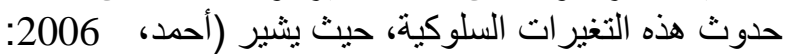

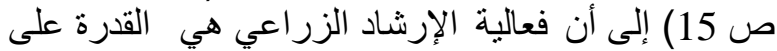

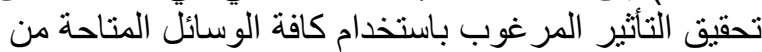

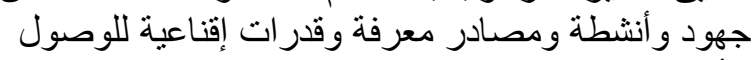

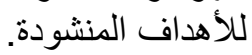

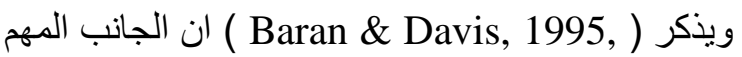

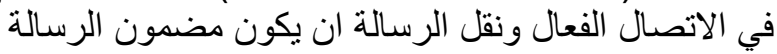

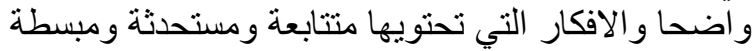
وتثير احتياجات محددة.

هذا ويعد محصول الطماطم ذو أهمية كبيرة من حيث الفيث

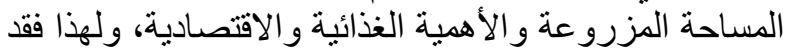

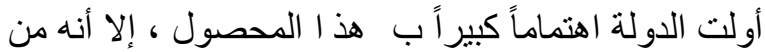
الملاحظ أن هنالك كثير من الأنشطة و الخدمات الإرشادية الرادية

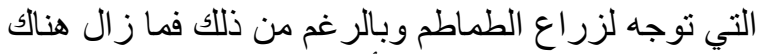

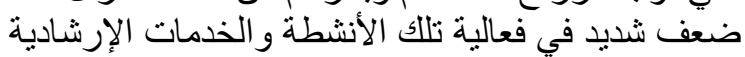

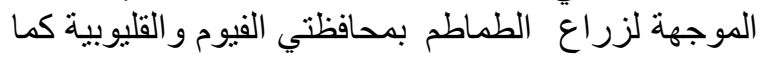

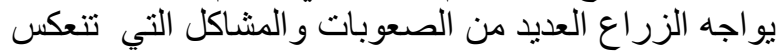

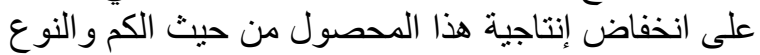

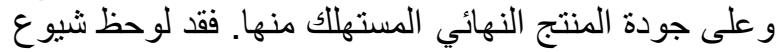

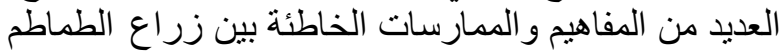

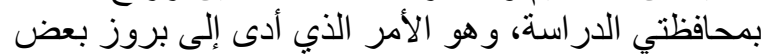

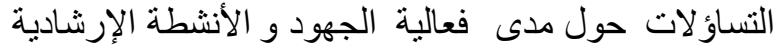

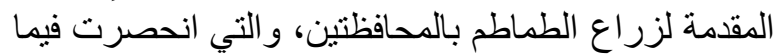
بلي: 1 - ماهي أهم المعارف و الممارسات الإرشادية التي يحتاج

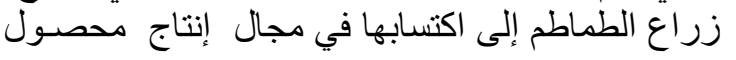


لقياس المتغير ات المستقلة، وثنانيها تحديد فعالية الإرشاد

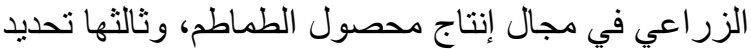

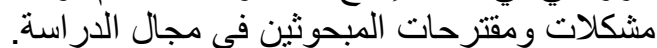

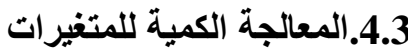
1.4.3. المتفيرات المستقلة المئة

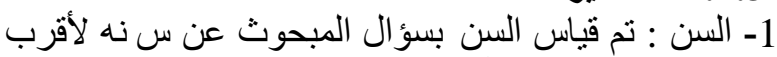
سنة ميلادية، معبر أ عنه بالأرقام الخام.

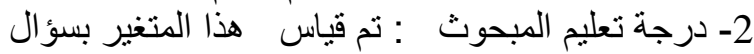

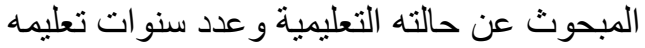

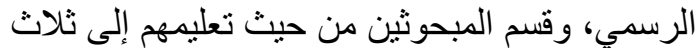

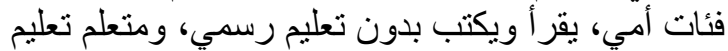

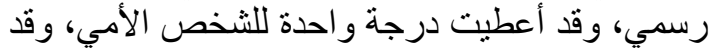

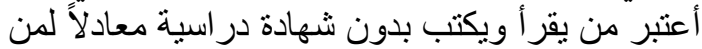

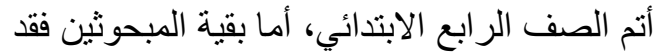

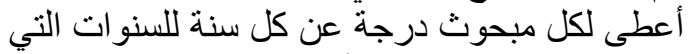

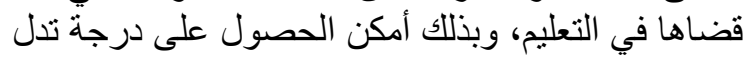

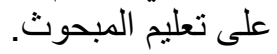

3- مساحة الحيازة الزراعية: تم قياس هذا المتغير من خلال

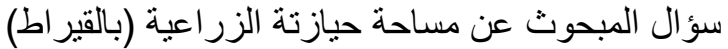

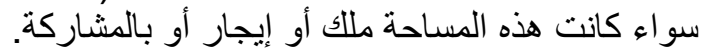

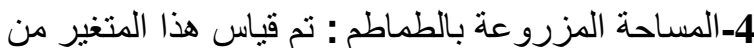

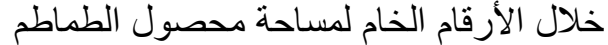
(بالقير اط) خلال سنة 2011 م . 5- منوسط إنتاجية فدان الطماطم تم قياس هذاس مذا المتغير من

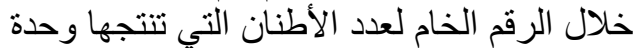

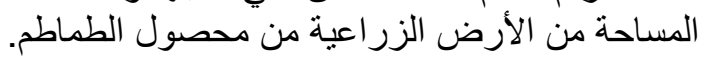

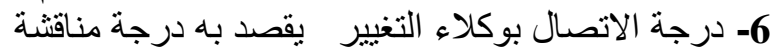

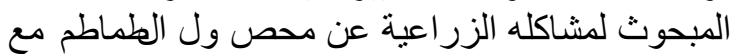

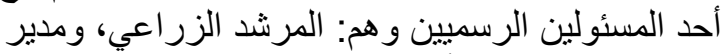

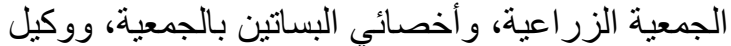

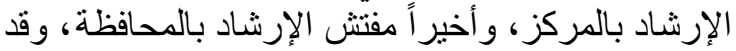

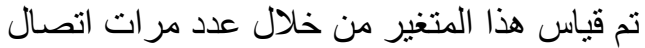

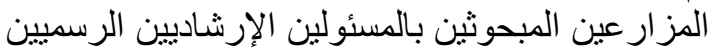

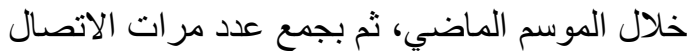

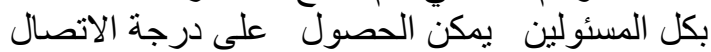

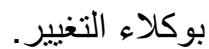

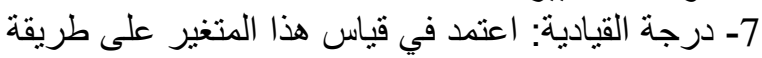

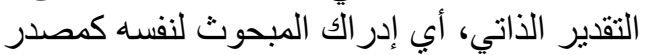

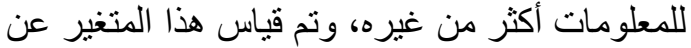

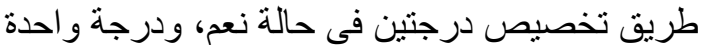
في حالة لا لكل عبارة من العبار ات الخاصة بئن بينود

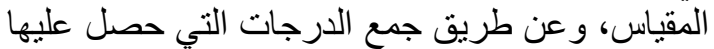

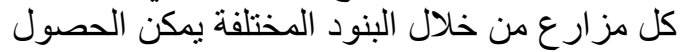

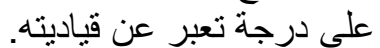

8- درجة الاتجاه نحو الأنشطة الإرشادية : استخدم في

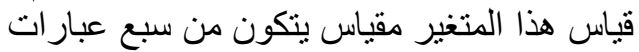
اعنبرت كل عبارة منها متدرجة لأنماط الاستجابة،

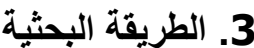

التعريف الإجرائي فعالية الإرشاد الزّراعي في مجال إنتاج محصول الطماطم يقصد بها في هذا البحثي

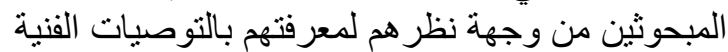

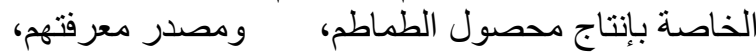
ودرجة تنفيذهم لهذه التوصيات، ودئ ودرجة استفادتهم من تنفيذ

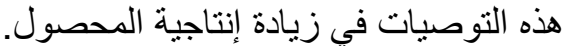
أي أن فعالية الإرشاد الزر اعي في مجال إنتاج محصول الترل

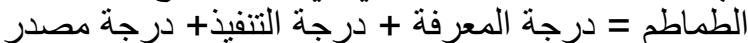
المعرفة + درجة الاستفادة من تنفيذ التوصيات

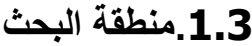

تم إجر اء هذهة الدراسة في محافظتي الفيوم و القليوبية باعتبار هما من أكبر محافظات الجمهورية من حيث التيث المساحة

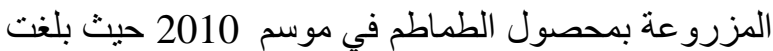

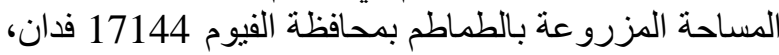

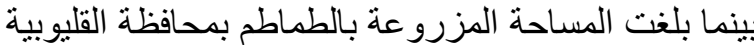

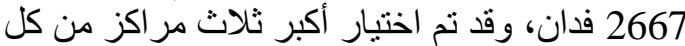

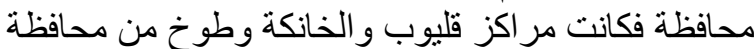

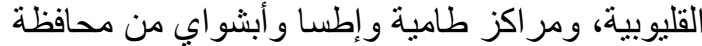

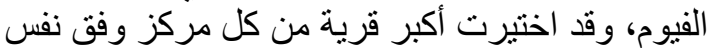

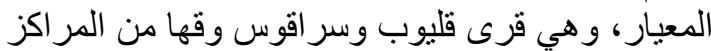

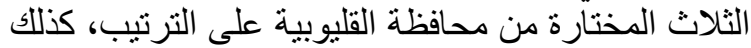

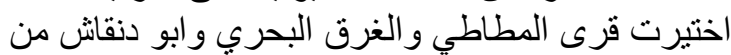

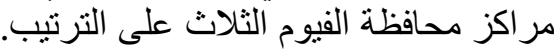
2.3 شاملة البحث وعينته

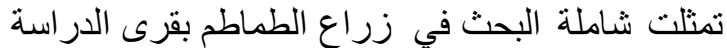
في ثلاث مر اكز بكل من محافظتي الفيوم و القليوبية و البالغ الغيلغ

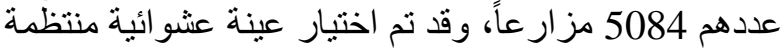

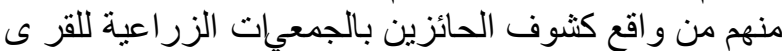

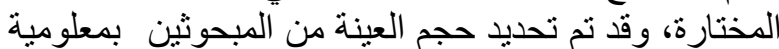
Krejcie\& حجم الثاملة باستخدام معادلة

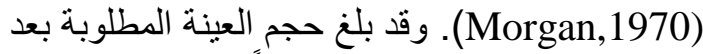
تطبيق هذه المعادلة 358 مز ارعاً بنسبة 7 \% من من إجمالية

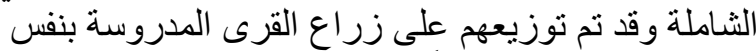

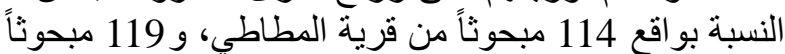

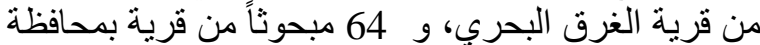

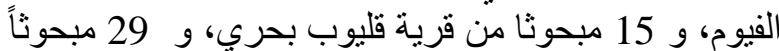
من قرية سر اقوس، و 17 مبحوثاً من قرية قها بمحافظة القلبوبية.

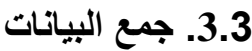

تم جمع البيانات الميدانية عن طريق استمارة استبيان

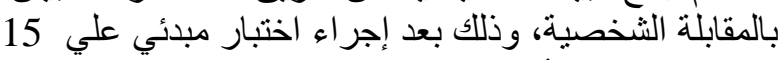
مبحوث من قرية أبو الغيط مركز القناطر الخيرية بمحافظة الفية

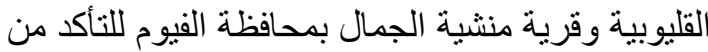

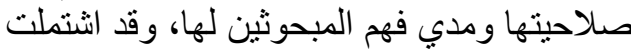
الاستمارة على ثلاثة أجزاء أولها مجموعة من الأسئلة 
الحاصل عليها المبحوث في كل استجابة من الاستجابات

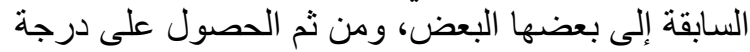
تعبر عن فعالية الإرشاد الزر اعي في مجال إنتاج محصول الطماطم.

4.3. 3. 3. البيانات الوصفية المشكلات التي تواجه زراع الطماطم

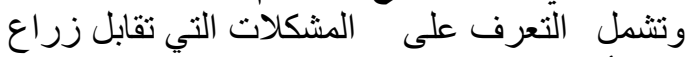

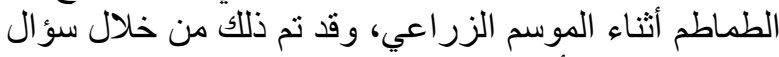

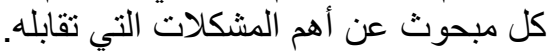
مقترحات زراع الطماطم المبحوثين للتظلب على المشكلات المثات

التي تواجهرم

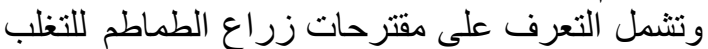

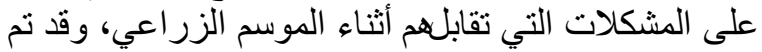

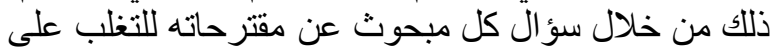
المشكلات التي تقابله. 4.4.3. أسلوب التحليل الإحصائي

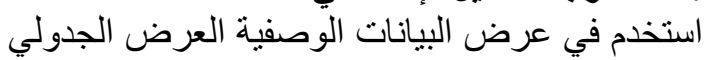

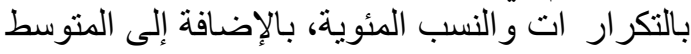

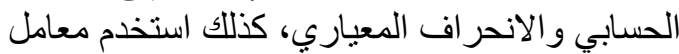

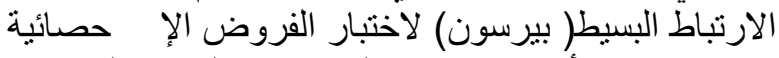

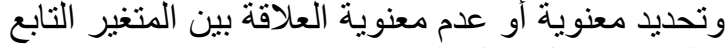

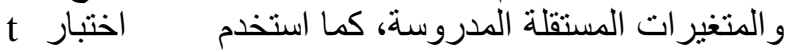
لاختبار معنوية الفروق بين درجات الفعالية بين محافظتي

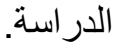

\section{4. النتائج ومناقشتها \\ 1.4. فعالية الإرشاد الزراعي في مجال إنتاج محصول الطماطم \\ 1.1.4. معرفة زراع الطماطم بالتوصيات الفنية الخاصة بإنتاجها}

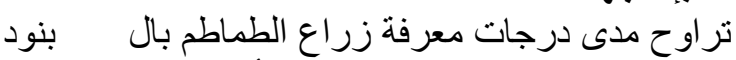
الثمانية المدروسة بين 4 درجات كحد أدنى، و 16 درجة درجة

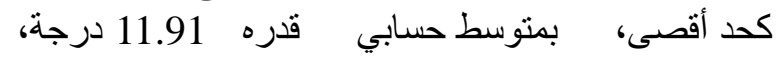
و وانحر اف معياري قدره 2.320، وقد تم تقديطيم المبحوثين

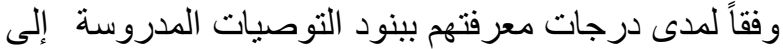

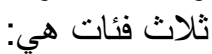
- معرفة منخفضة (أقل من 8 درجات)

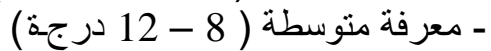
- معرفة مرتفعة ( أكثر من 12 درجة دنة)

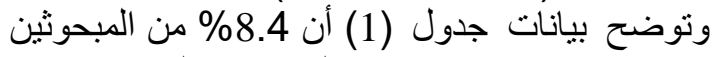

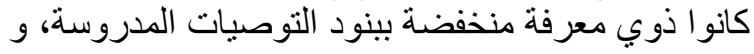

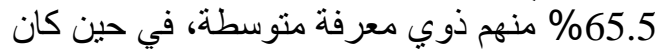

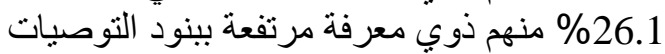

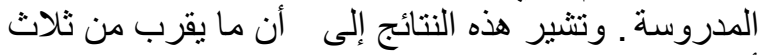

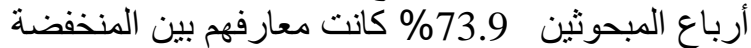

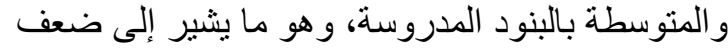

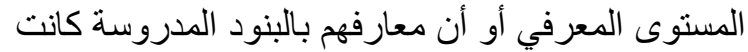

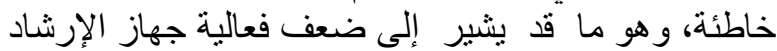

و الذي يتألف من ثلاث استجابات هي مو افق، سيان، غير

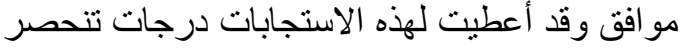
بين 3-1 في حالة العبار ات الإيجابية، و العكس في حالة الإنة

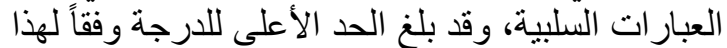

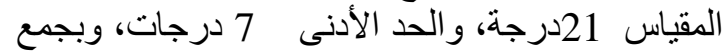
الدرجات التي يحصل عليها المبحوث من وندئ وحدات الزقياس يمكن الحصول على درجة تعبر عن الإن الجناه الزراع المبحوثين نحو الأنشطة الإرشادية. وبحساب

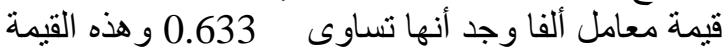
تشير إلي معامل ثبات مقبول. 2.4.3

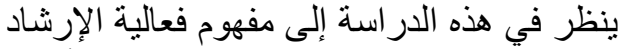

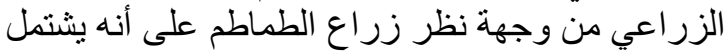

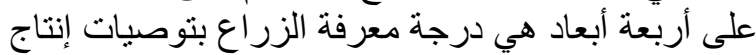

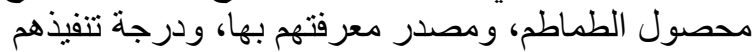

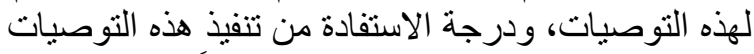

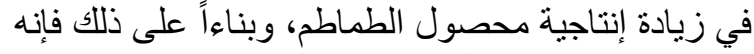

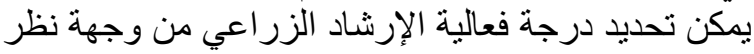

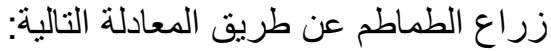

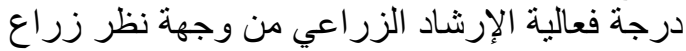
الطماطم = درجة معرفة الزراع الزعاع بتوصيات إنتاج محصول

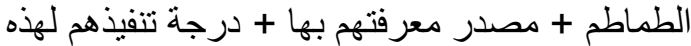

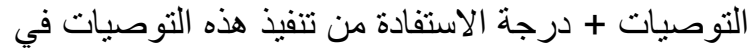

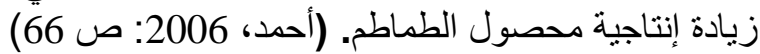

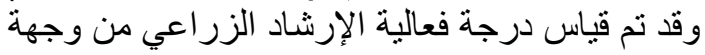

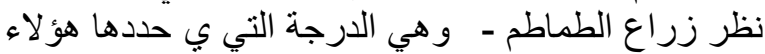

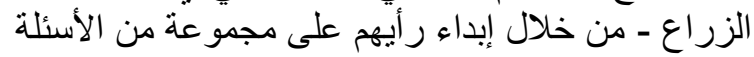

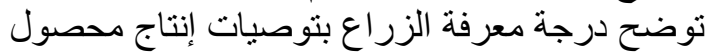

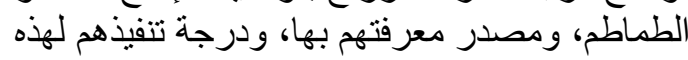

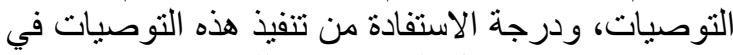

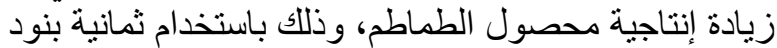

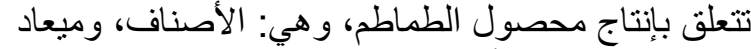

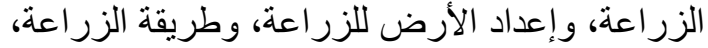

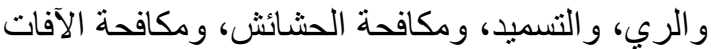

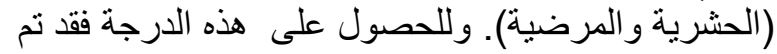

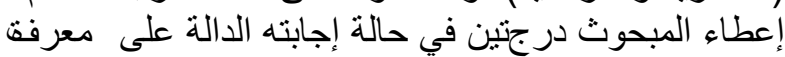

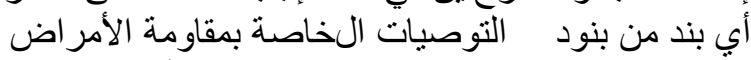

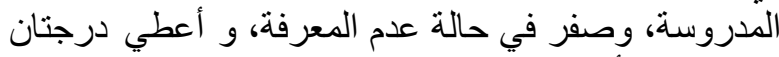

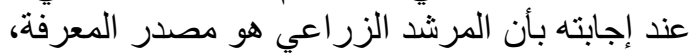

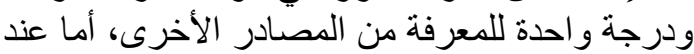

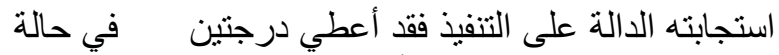

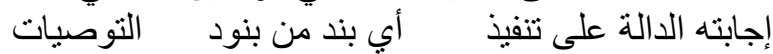

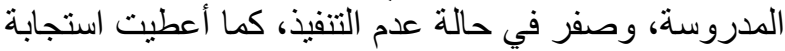
المبحوث الدالة على أستفادته بشكل كبير من تنفيذ التوصية التورية

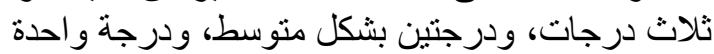

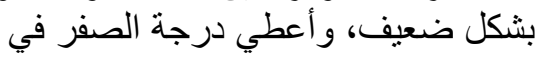

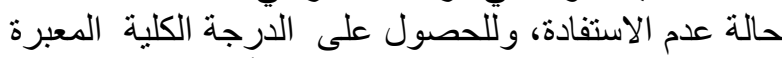
عن درجة الفعالية للإرشاد الزر اعي فقد أضيفت الدرجات الدي 


$$
\text { - تنفيذ مرتفع (أكثر من } 12 \text { درجة) }
$$

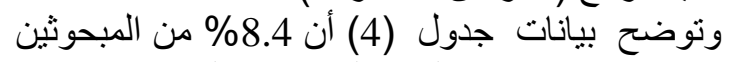

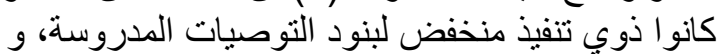

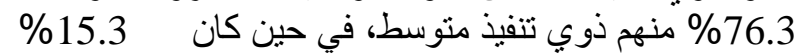

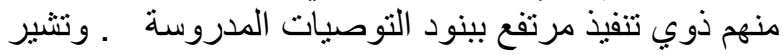

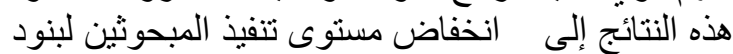
التوصيات المدروسة حيث كان مستوى تنفيذ الغالبية

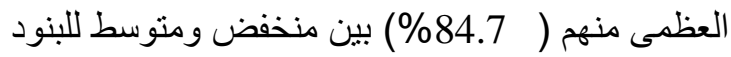

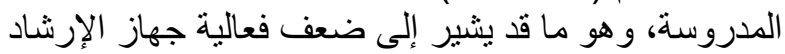

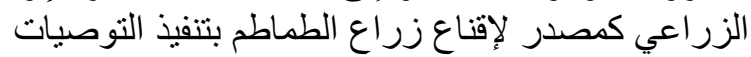
الفنية الصحيحة الخاصة بإنتاجها.

\subsection{4. استفادة زراع الطماطم من تنفيذ التوصيات الفنية} الخاصة بإنتاجها

تراوح مدى درجات استفادة زراع الطماطم من تنفيذ البنود

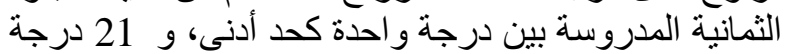

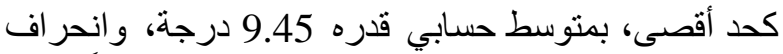

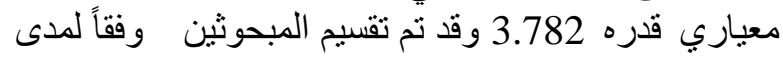

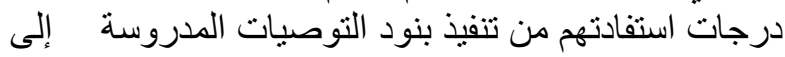

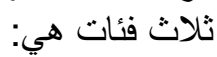
- استفادة منخفضة (أقل من 8 درجات) - استفادة مرتفعة (أكثر من 16 درجة دئة)

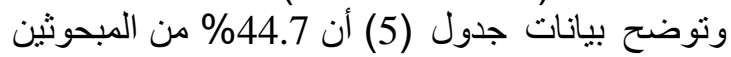

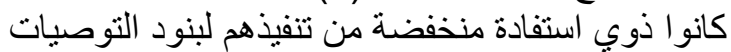

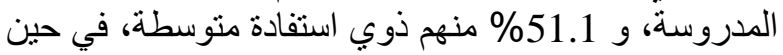

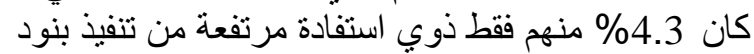

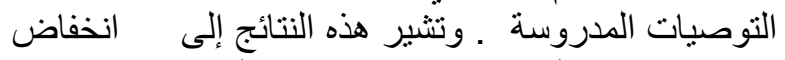

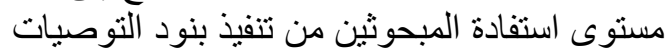

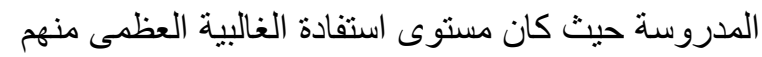

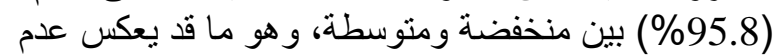
فعالية جهاز الإرشاد الزراعي في ولئ هذا المجال.

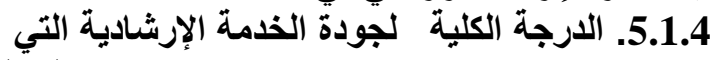

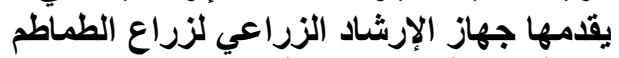

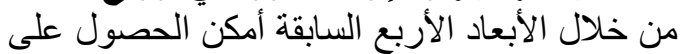

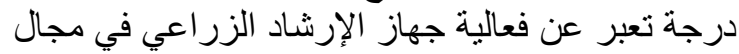

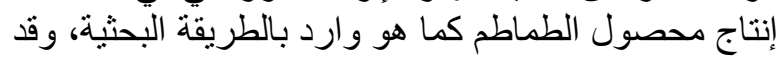

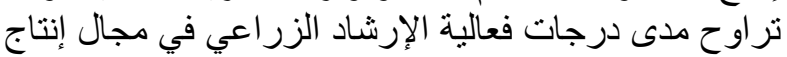
محصول الطماطم فيما يتعلق بالبنود المدروسة الزبة بين فين 18

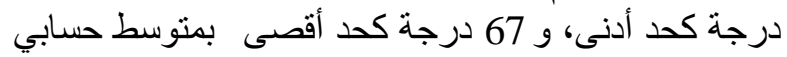

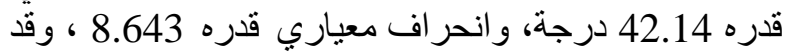

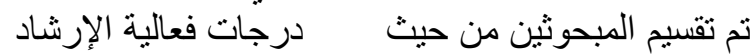
الزر اعي في مجال إنتاج محصول الطماطم إلى ثناث فئات الإنات

ـ فَعالية منخفضة (أقل من 34 درجات)

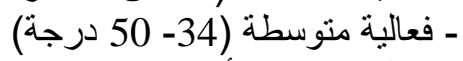
ـ فعالية مرتفعة (أكثر من 50 درجة درجة)
الزر اعي في تزويد زراع الطماطم بالمعلومات الصحيحة الخاصة بإنتاجها.

2.1.4. مصادر معرفة زراع الطماطم بالتوصيات الفنية

\section{الخاصة بإنتاجه}

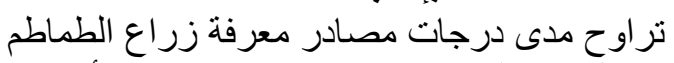

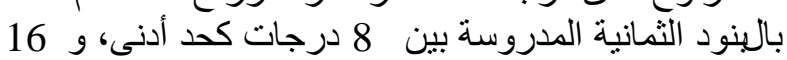

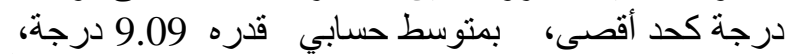

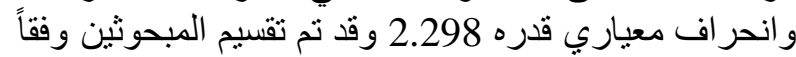

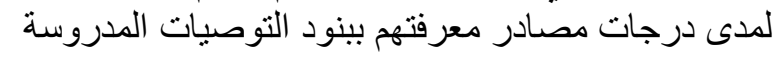

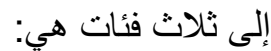

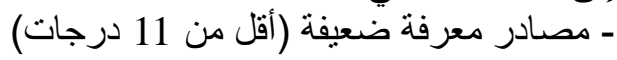
ـ - مصادر معرفة متوسطة (11- 13 درجة مرنة)

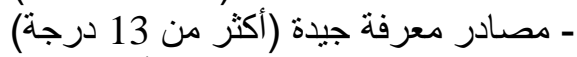

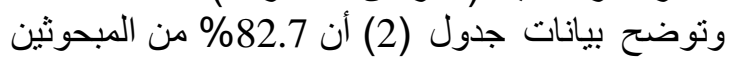
كانو ا ذوي مصنادر معرفة ضيات ضعيفة بينود التوصنيات

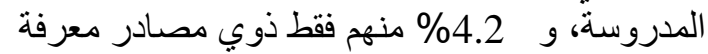

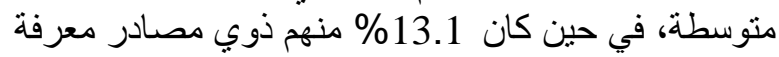

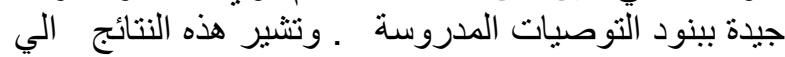

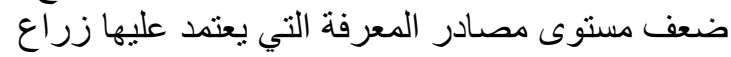

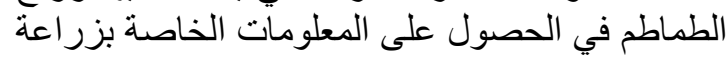

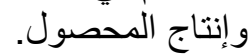
ويؤكد ذلك ما تشير إليه نتائج الجدول رقم (3) و الخاصة

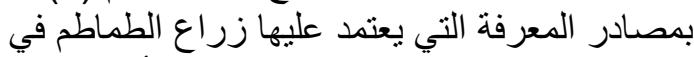

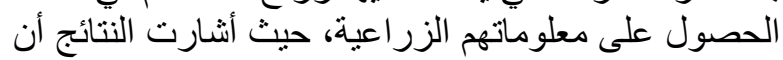

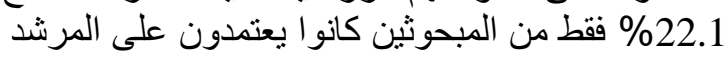

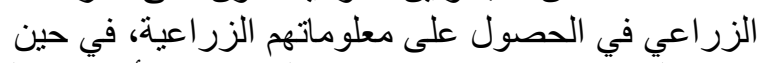

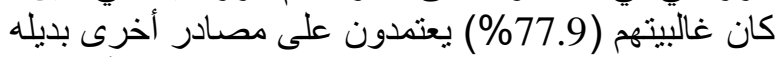

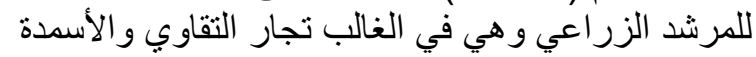

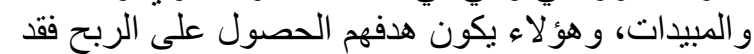

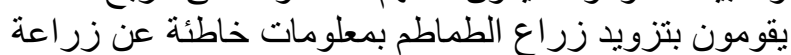

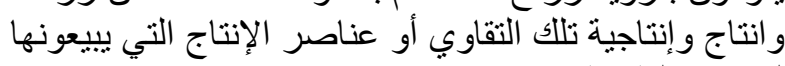

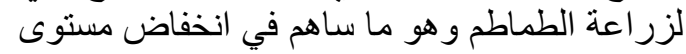

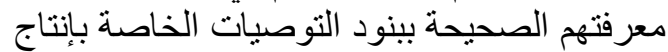

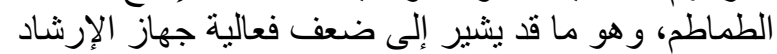

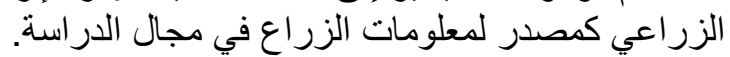

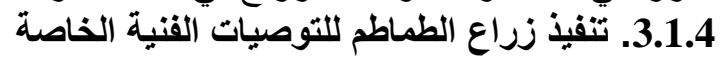
بإنتاجها

تراوح مدى درجات تنفيذ زر اع الطماطم للبنود الثمانية

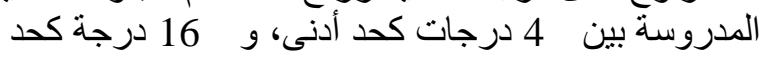

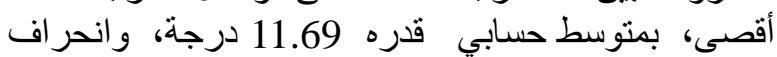

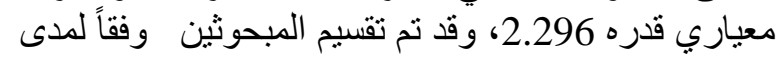
درجات تتفيذهم لبنود التوصيات المدروسة إلى ثلاث فئئات

ـ تيفيذ منخفض (أقل من 8 درجات) - تنفيذ منوسط (8- 12 درجة) 
جدول (1): توزيع المبحوثين وفقاً لمستوى معرفتهم ببنود التوصيات المدروسة.

\begin{tabular}{|c|c|c|}
\hline$\%$ & عدد & مستوى المعرفة \\
\hline 8.4 & 30 & معرفة منخفضة (أقل من 8 درجات) \\
\hline 65.5 & 235 & معرفة متوسطة (8- 12 درجة) \\
\hline 26.1 & 93 & معرفة مرتفعة (أكثر من 12 درجة) \\
\hline 100 & 358 & الإجمالي \\
\hline
\end{tabular}

جدول (2) توزيع المبحوثين وفقاً لمستوى مصادر معرفتهم ببنود التوصيات المدروسة.

\begin{tabular}{|c|c|c|}
\hline$\%$ & عدد & مستوى مصادر المعرفة \\
\hline 82.7 & 296 & مصادر معرفة ضعيفة (أقّل من 11 درجات) \\
\hline 4.2 & 15 & مصادر معرفة متوسطة (11- 13 درجة) \\
\hline 13.1 & 47 & مصادر معرفة جيدة (أكثر من 13 درجة) \\
\hline 100 & 358 & الإجمالي \\
\hline
\end{tabular}

جدول (3): توزيع المبحوثين وفقاً لمصادر معرفتهم ببنود التوصيات المدروسة.

\begin{tabular}{|c|c|c|}
\hline$\%$ & عدد & مصادر المعرفة \\
\hline 77.9 & 279 & المرشد الزراعي \\
\hline 22.1 & 79 & مصادر أخرى \\
\hline 100 & 358 & الإجمالي \\
\hline
\end{tabular}

جدول (4): توزيع المبحوثين وفقاً لمستوى تنفيذهم لبنود التوصيات المدروسة.

\begin{tabular}{|c|c|c|}
\hline$\%$ & عدد & مستوى التنفيذ \\
\hline 8.4 & 30 & تتفيذ منخفض (أقل من 8 درجات) \\
\hline 76.3 & 273 & تنفيذ متوسط (8- 12 درجة) \\
\hline 15.3 & 55 & تنفيذ مرتفع (أكثر من 12 درجة) \\
\hline 100 & 358 & الإجمالي \\
\hline
\end{tabular}

جدول (5): توزيع المبحوثين وفقاً لمستوى استفادتهم من تنفيذ بنود التوصيات المدروسة:

\begin{tabular}{|c|c|c|}
\hline$\%$ & عدد & مستوى الاستفادة \\
\hline 44.7 & 160 & استفادة منخفضة (أقل من 8 درجات) \\
\hline 51.1 & 183 & استفادة متوسطة (9- 16 درجة) \\
\hline 4.2 & 15 & استفادة مرتفعة (أكثر من 16 درجة) \\
\hline 100 & 358 & الإجمالي \\
\hline
\end{tabular}

جدول (6) : توزيع المبحوثين وفقاً لمستوى فعالية الإرشاد الزراعي في مجال إنتاج

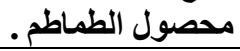

\begin{tabular}{|c|c|c|}
\hline$\%$ & عدد & مستوى الفعالية \\
\hline 13.7 & 49 & فُعالية منخفضة (أقل من 34 درجات) \\
\hline 72.4 & 259 & فُعالية متوسطة (34- 50 درجة) \\
\hline 13.9 & 50 & فعالية مرتفعة (أكثر من 50 درجة) \\
\hline 100 & 358 & الإجمالي \\
\hline
\end{tabular}


الإحصائي فيما يتعلق بالمتغير ات المستقلة المدروسة

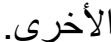

7.1.4. الفروق بين درجات فعالية الإرشاد الزراعي في الإي مجال إنتاج محصول الطماطم في محافظتي الآدرأسة

لتحقيق هذه الفروق تم صياغة الفرض البن البحثي التالي

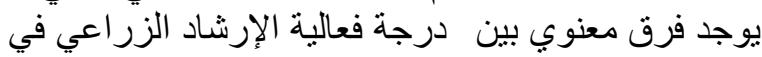

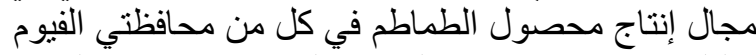

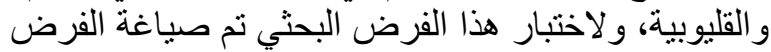

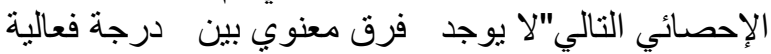
الإرشاد الزي الزي في مجال إنتاج محصول فئ الطماطم في كل

من محافظتي الفيوم و القليوبية، ولاختيار الإن هذا الفرق تم استخدام اختبار

وتوضح بيانات جدول ( 8) وجود فرقاً معنوياً بين درجات فعالية الإرشاد الزراعي في مجال إنتاج محصول

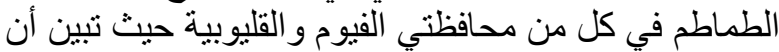

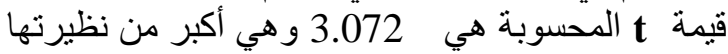

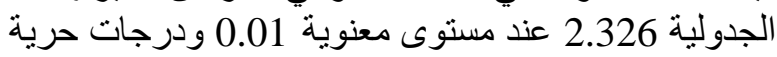
356، وكانت متوسطات درجات فعالية الإرشاد الزر اعي

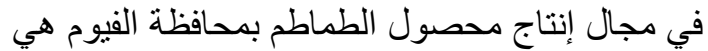

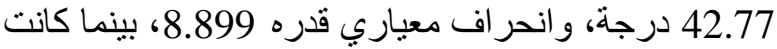

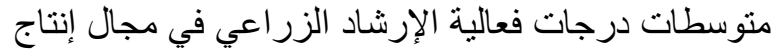

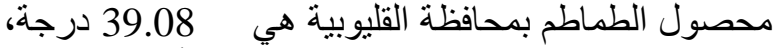

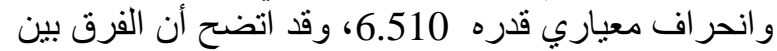

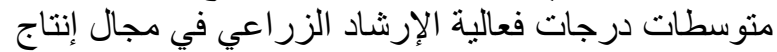

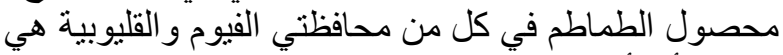

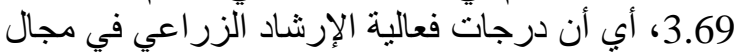

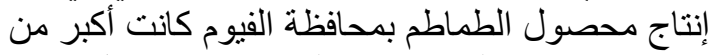

درجات جودة فعالية الإرشاد الزراعي في مجال إنتاج

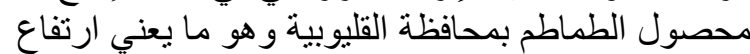

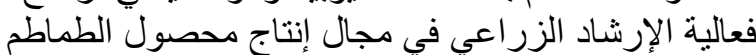

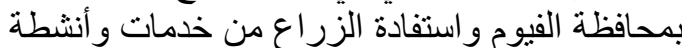

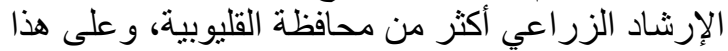

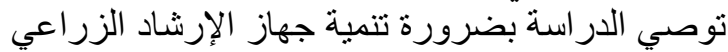

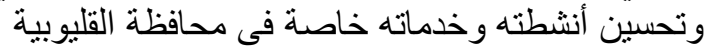
باعتباره المصدر الأول لتقديم الأنشطة والخدمات الإرشادية

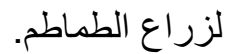

8.1.4. المشكلات التي تواجه زراع الطماطم في مجال إنتاجها

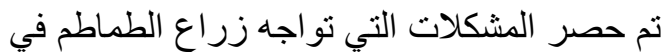

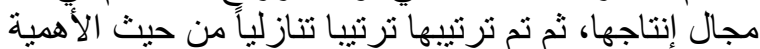

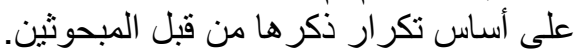

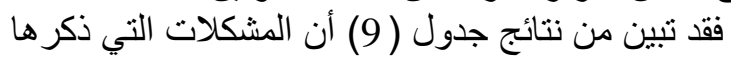
المبحوثين بلغ عددها عشر مشكلات وكان أكثر هان أهنان أهمية هو مشكلة انخفاض إنتاجية الفدان حيث ذكر ها

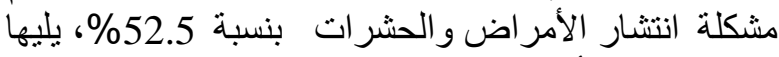
مشكلة ارتفاع أسعار الشتلات بنسبة 46.4\%، ثم 5شكلة

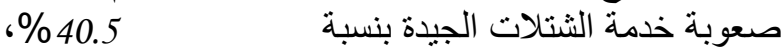
ومشكلة عدم إتباع دورة زر اعية بنسبة 36.9 \%، ثم مشكلة

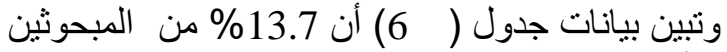

يرون أن الإرشاد الزر اعي ذول فعالية منخفضة في مجال

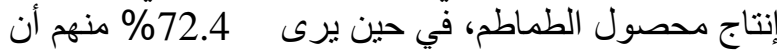

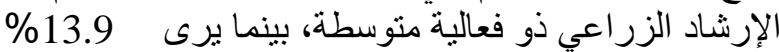
منهم أنه ذو فعالية مرتفعة.

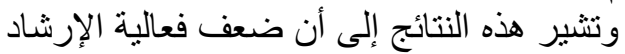

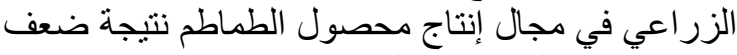

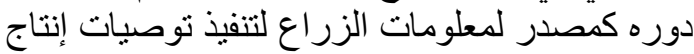

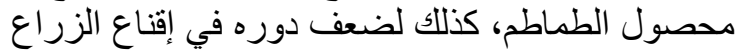

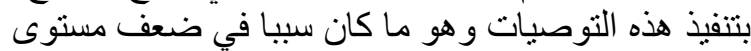

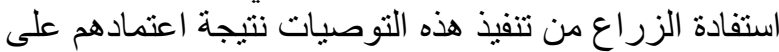

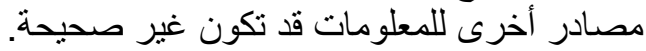

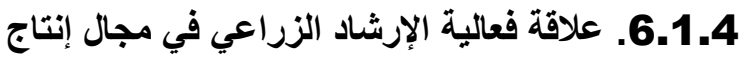
محصول الطماطم كمتغير تابع بيعض الإض في المتغيرات المستقلة المدروسة الطماطية

لاختبار هذه العلاقة تم صياغة الفرض المرضية البحثي التالي"

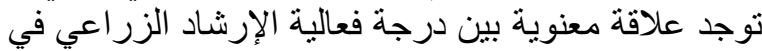

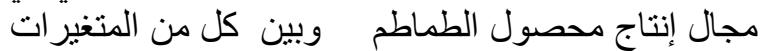

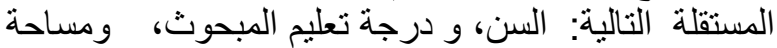

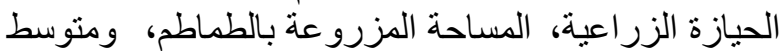

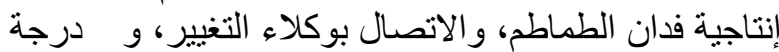

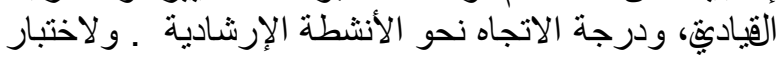

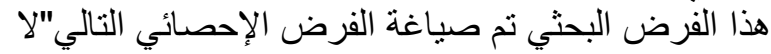

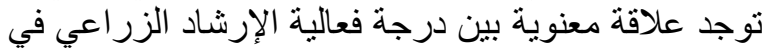

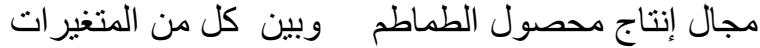
المستقلة سابقة الذكر ، و لاختبار هذه العلاقة نم استخدام معامل الارتباط البسيط لبيرسون.

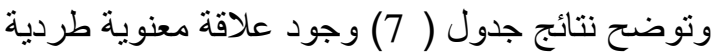

عند مستوى معنوية 0.01 بين درجة فعالية الزية الإرشاد

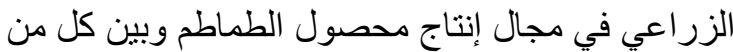

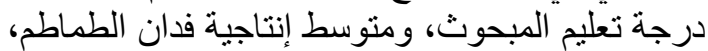

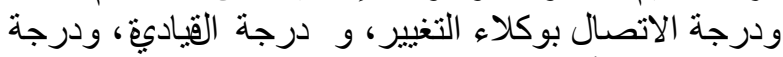
الاتجاه نحو الأنشطة الإرشادية ، وكانت العلاقة معنوية العادية ودرية

طردية عند مستوى معنوية 0.05 مع مساحة الإنية الحيازة العادية

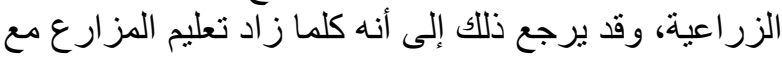

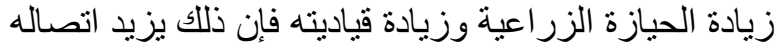

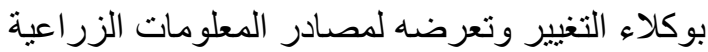

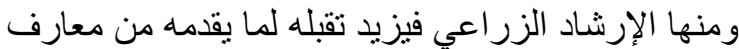

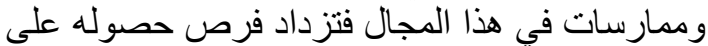
التوصيات الزر اعية المتعلقة بإنتاج محصول فئر الطماطم فتزيد

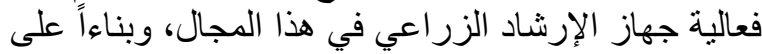

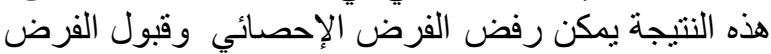

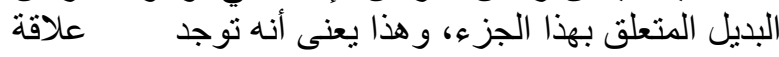

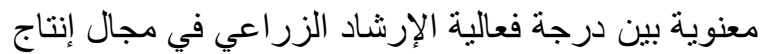

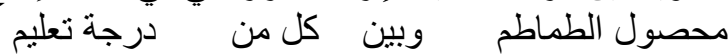
المبحوث ، ومساحة الحيازة الزر اعية ، ومتوسط إنتاجية

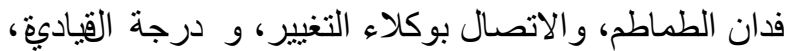
ودرجة الاتجاه نحو الأنشطة الإرشادية، وقبول الفرال الفرض الفارة 
جدول(7): قيم معاملات الارتباط بين الدرجة الكلية لفعالية الإرشاد الزراعي في مجال إنتاج محصول الطماطـم وبعض المتغيرات المستقلة المدروسة.

\begin{tabular}{|c|c|c|c|c|}
\hline قيم معامل الارتباط & الالمعراف & الحستوسب & المتغيرات المستقلة المدروسة & b \\
\hline 0.068 & 10.861 & 49.09 & السن & 1 \\
\hline$* * 0.300$ & 5.125 & 5.51 & درجة تعليم المبحوث & 2 \\
\hline$* 0.123$ & 37.935 & 49.64 & مساحة الحيازة الزراعية & 3 \\
\hline 0.077 & 22.856 & 33.64 & المساحة المزروعة بالطماطر & 4 \\
\hline$* * 0.164$ & 13.640 & 22.77 & متوسط إنتاجية فدان الطماط & 5 \\
\hline$* * 0.237$ & 5.832 & 6.91 & الاتصال بوكلاء التغيير & 6 \\
\hline$* * 0.247$ & 8.812 & 12.54 & درجة القيادية & 7 \\
\hline$* * 0.214$ & 0.986 & 14.48 & درجة الاتجاه نحو الأنثطة الإرشادية & 8 \\
\hline
\end{tabular}

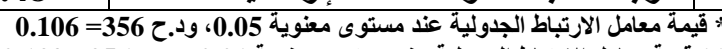
** قيمة معامل الارتباط الجدولية عند مستوى معنوية 0.01، ود. ح ح $356=0.0139$

جدول (8): معنوية الفروق بين درجات فعالية الإرشاد الزراعي في مجال إنتاج محصول الطماطم في كل من محافظتي الفيوم والقليوبية.

\begin{tabular}{|c|c|c|c|c|}
\hline المحسوبة & الفتوسطات & المعياري & المتوسط & البيـان \\
\hline \multirow{2}{*}{3.072} & \multirow{2}{*}{3.69} & 8.899 & 42.77 & محافظة الفيوم \\
\hline & & 6.510 & 39.08 & محافظة القليوبية \\
\hline
\end{tabular}

\begin{tabular}{|c|c|c|c|}
\hline & & \multicolumn{2}{|c|}{ جدول رقم ( 9): المشكلات التي تواجه زراع الطماطح } \\
\hline$\%$ & تكرار & 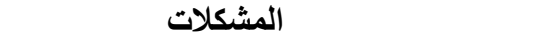 & p \\
\hline 58.9 & 211 & انخفاض إنتاجية الفدان & -1 \\
\hline 52.5 & 188 & انتشار الأمر اض والحشرات & -2 \\
\hline 46.4 & 166 & ارتفاع أسعار الثتلات & -3 \\
\hline 40.5 & 145 & صعوبة خدمة الشتلات الجيدة & -4 \\
\hline 36.9 & 132 & عدم إتباع دورة زراعية & -5 \\
\hline 36.6 & 131 & عدم وجود العمالة الماهرة وارتفاع أجورها & -6 \\
\hline 34.1 & 122 & ارتفاع أسعار الأسمدة والمبيدات & -7 \\
\hline 24.6 & 88 & ارتفاع أسعار إيجارات الأراضي & -8 \\
\hline 20.1 & 72 & علدم توفز الأصناف الجيدة & -9 \\
\hline 14.2 & 51 & قلمّة الندوات و الأنشطة الإرشـادية & 10 \\
\hline
\end{tabular}

جدول (10): مقترحات زراع الطماطم للتظلب على المشكلات الإنتاجية .

\begin{tabular}{|c|c|c|c|}
\hline$\%$ & 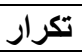 & المقترحات & p \\
\hline $\mathbf{5 0 . 6}$ & 181 & توفير عناصر الإنتاج الزراعي بأسعار رخيصة & -1 \\
\hline 48.3 & 173 & إتباع الدورة الزراعية & -2 \\
\hline 46.4 & 166 & الخدمة الجيدة & -3 \\
\hline 46.1 & 165 & الرش بالكبريت لتقليل استخدام المبيا & -4 \\
\hline 45.3 & 162 & عدم الإِسراف في استخدام الأسمدة والمبيدات & -5 \\
\hline 37.2 & 133 & زراعة أُصناف تتحمل الأمراض & -6 \\
\hline 21.5 & 77 & الاهتمام بالندوات والأنشطة الإرشادية & 7 \\
\hline
\end{tabular}




$$
\begin{aligned}
& \text { الإدارة المركزية للاقتصاد الزراعي (2010). وزارة }
\end{aligned}
$$

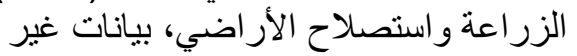

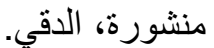

$$
\begin{aligned}
& \text { المركز الدولي للبطاطس (2005). زر اعة و إنتاج الطماطم }
\end{aligned}
$$

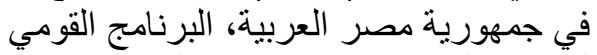

$$
\begin{aligned}
& \text { لزر اعة البطاطس، مصر مر - هولندا. }
\end{aligned}
$$

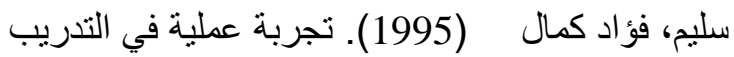

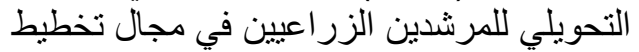

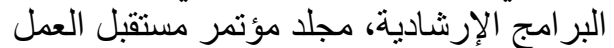

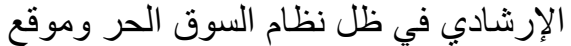

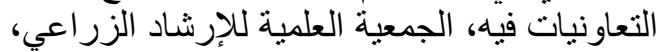

$$
\begin{aligned}
& \text { المركز المصري الدولي للزر اعة، الدئي. }
\end{aligned}
$$

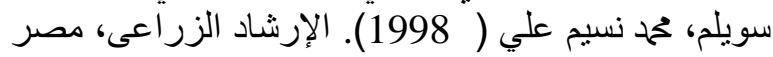

$$
\begin{aligned}
& \text { للخدمات العلمية، القاهرة. } \\
& \text { سويلم، محمد نسيم علي (2003). التوأمان الكفاءة و الفعالية، } \\
& \text { مصر للخدمات العلمية، القاهرة. } \\
& \text { سليمان، حنفي ( 1987). العلوم السلوكية، كلية التجارة، الزفة الزفة } \\
& \text { جامعة الزقازيق، الزقازيق. }
\end{aligned}
$$

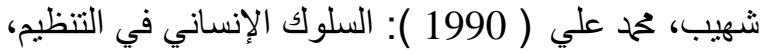

$$
\begin{aligned}
& \text { مطبعة جامعة القاهرة، الكتاب الجامعي الطبعة الأباني }
\end{aligned}
$$

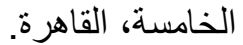

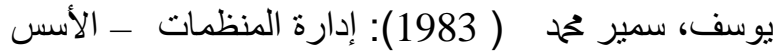

$$
\begin{aligned}
& \text { النظرية و النو احي التطبيقية، الطبعة الثانية، دار النئية } \\
& \text { الفكر العربي، القاهرة. }
\end{aligned}
$$

Baran J. S. and Davis K. D. (1995) . Mass

Communication Theory, Foundations

Ferment and Future, Printed in the

United States of America, Publishing

Company, Belmont, California.

Krejcie R. and Morgan D. W. (1970).

"Determining Sample Size For Research

Activities in Educational and

Psychological Measurement, Vol. (30),

Published By College Station, Durham,

North Carolina, USA.

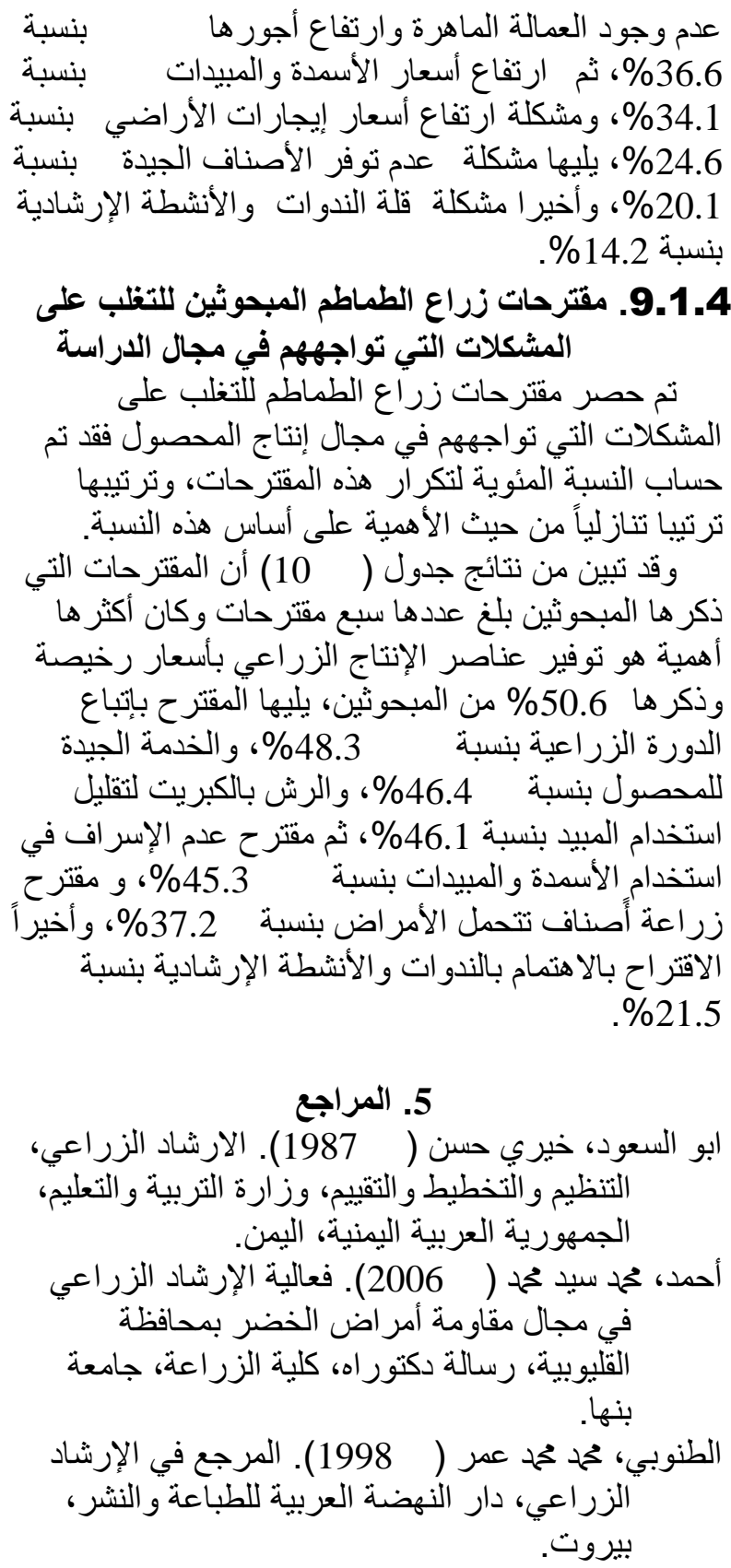

